\title{
ФОРМИРОВАНИЕ ТРАДИЦИЙ ИНСТРУМЕНТАЛЬНОГО КОНЦЕРТА В МОЛДАВСКОЙ МУЗЫКЕ СЕРЕДИНЫ ХХ ВЕКА (НА ПРИМЕРЕ КОНЦЕРТА №2 ДЛЯ ФОРТЕПИАНО С ОРКЕСТРОМ В. ПОЛЯКОВА)
}

\author{
Варданян Алёна Альфредовна \\ кандидат искусствоведения и культурологии, и.о. профессора \\ Академии музыки, театра и изобразительных искусств, \\ Кишинев, Республика Молдова
}

\begin{abstract}
Аннотация. В статье анализируется Концерт № 2 для фортепиано с оркестром В. Полякова с точки зрения его роли в развитии жанра инструментального концерта в молдавской музыке. Делается вывод о синтетическом типе драматургии произведения, о конкретно-ассоциативном подходе к преломлению фольклорных элементов и об опоре молдавского композитора на существовавшие к тому времени универсальные традиции.

Abstract. The article analyzes V. Polyakov's Piano Concerto No. 2 from the point of view of his role in the development of the instrumental Concerto genre in Moldovan music. The conclusion is made about the synthetic type of dramaturgy of the work, about the concrete associative approach to the refraction of folklore elements and about the Moldovan composer's reliance on universal traditions that existed at that time.

Ключевые слова: концерт для фортепиано с оркестром, молдавский фольклор, драматургия, композиция, традиция.

Keywords: Piano Concerto, Moldovan folklore, dramaturgy, composition, tradition.
\end{abstract}

Второй фортепианный концерт В. Полякова (1955) - яркий пример того, как в молдавском искусстве происходило становление и развитие концертного жанра. С одной стороны, данное сочинение отражает типичное для начального этапа эволюции инструментальной музыки тяготение к лирико-жанровой сфере образов и опору на национальный фольклор (так называемую «национализацию» жанра). С другой стороны, названный концерт демонстрирует синтетический тип драматургии и своеобразное сочетание принципов лирической, эпической и драматической поэтик, что станет показательным для молдавских авторов в дальнейшем.

Возникновение Концерта № 2 для фортепиано с оркестром В. Полякова относится к первому послевоенному десятилетию, когда развитие жанров симфонической музыки отличалось динамичным характером и возросшей активностью молдавских композиторов в области инструментального концерта. До появления указанного сочинения в Молдове было создано только три концертных опуса: скрипичные Шт. Няги (1944) и Д. Гершфельда (1951), а также фортепианный Д. Федова (1952)1. Отметим, что В. Поляков был одним из первых композиторов Молдавии, кто активно использовал ресурсы данного жанра: он является автором Концертино для оркестра с солирующим гобоем (1952), скрипичного (1953) и виолончельного (1960) концертов. Все они стали важной вехой не только в эволюции стиля композитора, но и в развитии концертного жанра в Молдове.

В конце 1950-х - начале 1960-х гг. другие молдавские композиторы тоже начали интенсивно обращаться к данному жанру. Так, в монографии В. Аксенова «Молдавская симфония. Историческая эволюция разнообразия жанров» [2] в этой связи упоминаются концерты для скрипки с оркестром А. Муляра (1955) и Г. Гершфельда (1960), а также два концерта С. Лобеля: скрипичный (1956) и фортепианный (1957).

Стиль Второго фортепианного концерта В. Полякова тесно связан с традиционной молдавской музыкой: будучи прекрасным знатоком народного творчества, автор глубоко и тонко чувствовал его национальную специфику и убедительно воплотил в музыкальном языке анализируемого произведения фольклорные элементы.

Данный фортепианный опус В. Полякова продолжает академические традиции большого классицистскоромантического концерта для солиста и симфонического оркестра с присущими ему традиционными темповыми соотношениями частей, подчеркнутыми яркими тематическими контрастами. Во взаимоотношениях солиста и оркестра важную роль играет принцип концертирования, по-разному реализованный в каждой из частей: в крайних - партия рояля включена в общее звучание как равноправный участник музыкального действа, а во второй - противостоит оркестру как ведущий солирующий компонент.

Концерт отличается целостностью концепции благодаря интонационной близости тематического материала. Связи между частями обеспечиваются наличием нескольких интонационных формул, которые гарантируют тематическое единство целого при непрерывном характере развития контрастных образных сфер.

\footnotetext{
${ }^{1}$ Первый фортепианный концерт В. Полякова не включен в этот список: во-первых, он был создан в 1948 году, когда композитор жил за пределами Молдовы, а во-вторых, он недоступен для исследования, поскольку партитура утеряна [5].
} 
Диалектическое взаимодействие диаметрально противоположных характеров можно заметить уже в первой части, которая написана в форме сонатного аллегро. Сравнение двух «персонажей»: веселого, игривого, иногда даже саркастичного, с одной стороны, и мелодичного, балладно-повествовательного - с другой, традиционно реализуется в соотношении главной и побочной партий. Их индивидуализации способствует различие в метроритмической и тональной сферах.

В теме главной партии народное начало подчеркивается, прежде всего, ладовой основой, где тональность $C$-dur усложнена повышенными II и IV ступенями, характерными для молдавских модусов, а встречающиеся фрагменты с увеличенной секундой сообщают теме восточный колорит. Связующая, образованная на основе главной, строится на последовательности тональностей $G$-dur и $E s-d u r$ и предвосхищает побочную, лирическое выражение которой раскрывается уже в начальной сдержанной интонации, где каждый звук подчеркивается авторским указанием tenuto. Побочная тема производна от главной, она сохраняет с ней связь посредством одного из мотивов, выступающего в качестве основы для обеих тем. Композитор использует апробированные методы повышения «эмоциональной температуры»: партия солиста максимально насыщена остинатными формулами и пассажами в октавных дублировках.

Тематический материал побочной партии получает существенное развитие уже в экспозиции, что, вероятно, объясняет решение композитора не использовать его в среднем разделе формы, где непрерывное динамическое нарастание достигает своего пика. В репризе побочная тема исполняется сначала солирующим инструментом, а позже появляется в оркестре. «Порхающие» арпеджированные пассажи пианиста привносят в ее лирический образ утонченность и легкость. Трактуя данную тему как ведущий поэтический символ всей первой части концерта, В. Поляков основывает на ней начальный раздел фортепианной каденции. Введенная перед кодой, она подтверждает неисчерпаемую силу ключевых интонационных образов, творчески интерпретированных композитором в тематическом профиле концерта. Драматургическое развитие каденции опирается на фактурное, регистровое и динамическое разнообразие: накопление энергии начинается со скромных, «акварельных» звучаний; проходит фазу возрастания шкалы регистрового охвата и приводит к грандиозной кульминации, которая по звучанию может конкурировать с tutti оркестра.

В короткой оптимистичной коде композитор в партии солиста использует яркие средства музыкальной выразительности: динамичные октавные восходящие пассажи, мощную аккордику, широкое, гулко резонирующее тембральное пространство. Опираясь на традиции виртуозного фортепианного письма Ф. Листа и С. Рахманинова, молдавский композитор трансформирует их в собственный индивидуальный стиль.

Вторая часть (Lento cantabile), более лаконичная по сравнению с первой, написана в простой трехчастной форме. Лирическая глубина мелоса производит огромное впечатление с первых же звуков начальной темы. Медленная оркестровая интродукция по характеру близка к молдавской народной колыбельной, поэтому в процессе еe развертывания автор подчеркивает импровизационный тип изложения. Здесь доминирует медитативность, окрашенная нюансами внутренней тревоги. Изящная, изысканно украшенная основная тема поручена высокому регистру рояля. Дублированная в две октавы, она исполняется на фоне размеренных оркестровых аккордов. Прозрачность фактуры, исключительная яркость красок, характеризующие палитру оркестра и фортепиано, придают общему колориту особую трепетность и теплоту.

Средний раздел второй части отмечен усилением импровизационного начала, особенно в фортепианной партии. Композитор направляет музыкальное развитие на расширение общей динамики, проявляя гибкость в соединении лирико-медитативных и решительных импульсов. Звуковой объем и плотная текстура кульминации достигаются консолидацией фортепианной и оркестровой партий, расширением диапазона звучания до ff и резкими колебаниями темпа - от Lento cantabile до Allegro scherzando.

Краткий раздел Andantino возвращает слушателей к первоначальному настроению медитативной лирики. В целом во второй части концерта, как и в первой, тоже ощущается значительная интонационная близость двух основных тем, дающая возможность объединить лирическую и эпико-драматическую образные сферы. Общими элементами здесь служат секундовые интонации и экспрессивные восходящие квартовые ходы.

Третья часть Концерта № 2 для фортепиано с оркестром В. Полякова (Allegro giocoso) написана в форме рондо $(A-B-A 1-C R-A 2)$, где четвертый раздел формы $(\mathrm{CR})$ сочетает в себе признаки эпизода и разработки. В интонационно-тематической структуре финала отчетливо проявляются молдавские народные интонации, используемые автором как в мелодическом, так и в ритмическом аспектах. Композитор трактует их как средство для достижения близости к национальному стилю и реализует во включении эмоционально насыщенной, активной темы с ярко выраженной танцевальной окраской, прототипом которой стала народная песня «Bate vântul» («Дует ветер»).

Оценивая финал в композиции целого, необходимо отметить его виртуозный характер, проявляющийся в таком взаимодействии солиста и оркестра, которое приводит не к соперничеству, противостоянию и противодействию этих двух музыкальных главных героев, а к взаимному обогащению, их «слиянию» в едином звуковом потоке. Здесь отчетливо выражена тенденция к импровизационности, являющейся главным принципом изложения и развития материала и обусловливающей текучесть формы. В то же время финал, 
будучи завершением цикла, реализует функцию обрамления, арки, соединяющей его с первой частью. Стремительный по движению, танцевальный характер рефрена координируется с основной темой первой части.

Атмосфера праздничного финала, его активный, оптимистичный и жизнеутверждающий характер представлены с использованием жанровой танцевальной тематики, ассоциативно связанной с различными слоями молдавского национального фольклора. Его мастерское исполнение помогает создать достоверный, темпераментный эмоциональный образ.

Оценивая композиционно-драматургические особенности Концерта № 2 для фортепиано с оркестром В. Полякова с позиции его исторической значимости в молдавской музыке, можно убедиться в том, что в данном произведении использован синтетический тип драматургии, характерный для крупных циклических опусов того времени. Лирическое начало проявляется в яркой эмоциональной окраске тематизма, в стремлении композитора раскрыть разные грани душевного мира современника. Эпические черты заявляют о себе жанровой характерностью тематизма, опорой на фольклорность. Элементы драматической поэтики заключаются в преимущественном внимании композитора к уровню тематических процессов произведения: в акцентировании тематического слоя по сравнению с фоническим и синтаксическим иерархическими уровнями. В соотношении же данных типов драматургии преобладают черты эпоса и лирики.

Для Фортепианного концерта В. Полякова характерен в основном «обработочный», «конкретноассоциативный» подход к молдавскому мелосу: композитор использует два способа претворения фольклорного материала - цитирование (в финале) и создание ряда музыкальных тем в народном стиле (первая и вторая части).

В проанализированном произведении композитор опирается на существовавшие к тому времени универсальные традиции и развивает их. В музыкальной практике того периода уже был выработан соответствующий тип «национальной художественной формы» концерта: ориентиром являлись сочинения А. Хачатуряна. В. Поляков лишь перенес его на молдавскую национальную почку и, соответственно, трансформировал и обогатил конкретным интонационным содержанием. Нельзя не согласиться с Е. Клетиничем, что «...ныне невозможно уже представить себе музыку Советской Молдавии без симфоний и инструментальных концертов В. Полякова, без самой его личности - сильной и колоритной» [3, с. 50], и поэтому его творчество заслуживает пристального внимания, уважения и всяческой пропаганды.

\section{Литература}

1. Абрамова Э. Инструментальный концерт в творчестве композиторов Советской Молдавии. Кишинев: КГУ, 1988. - 49 с.

2. Аксенов,В. Молдавская симфония: историческая эволюция, разновидности жанра. - Кишинев: Штиинца, 1987. - 128 с.

3. Клетинич Е. Очерки о советских молдавских композиторах. - Кишинев: Литература артистикэ, 1984. - 196 с.

4. Мирошников А. Фортепианные произведения молдавских композиторов. - Кишинев: Штиинца, 1973. $-66 \mathrm{c}$.

5. Столяр 3. Композиторы молдавской ССР. - Москва: Советский композитор, 1960. - 224 с.

6. Флоря Э. Музыка народных танцев Молдавии. - Кишинев: Штиинца, 1983.- 134 с. 